
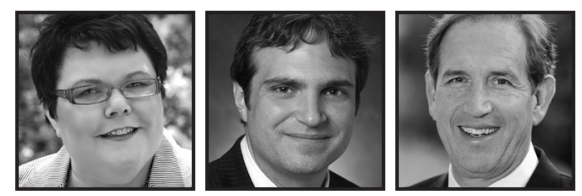

\title{
New Practices for a New Day: Principal Professional Development to Support Performance Cultures in Schools
}

Sally J. Zepeda, University of Georgia

Albert M. Jimenez, Kennesaw State University

Philip D. Lanoue, University of Georgia

\section{ABSTRACT}

This study focuses on principal professional development in one school system in the United States to support a performance culture. With the leadership of the superintendent and central office leaders, principal learning communities were established to foster shared learning and professional development that enhanced their roles as lead learners in their buildings. Three primary themes emerged from the research: Beliefs Matter Only if Growth Matters, Transformational Professional Development Builds a Performance Culture, and Effective Professional Development Provides Safe Landing Change. The themes support that leading is learning. The implications of the research lie primarily in the realm of practice.

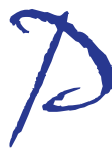

rincipals matter second only to teachers in promoting gains in student achievement (Heck \& Hallinger, 2009); hence, principals must foster the growth and development of teachers who are at the forefront of the instructional program in classrooms (Zepeda, Lanoue, Price, \& Jimenez, 2014). The work of leaders has changed swiftly and dramatically because "improving teaching quality and reducing the variability within that quality is a primary responsibility of school district leaders, building level leaders, and teachers" (Davis, 2013, p. 3).

In the United States, the No Child Left Behind Act of 2001 (NCLB) called for highly qualified teachers defined as ones who held an appropriate certificate or take measures 
to obtain one. In the U.S. context, teachers must be credentialed with appropriate certifications to teach; however, a highly qualified teacher is not necessarily an "effective teacher," often defined as a teacher who can directly improve student learning (Darling-Hammond, 2012). Data from a 2009 Wallace Foundation study report found that principals spend about $67 \%$ of their time focused on management functions (e.g., dealing with discipline) and $30 \%$ of their time focused on the instructional program (e.g., observing teachers, participating in professional development with teachers, providing feedback). The work of principals continues to evolve, often forcing them to make choices about where to expend effort, time, and attention. Professional development can be a tool for systems to support leaders to focus or to refocus time and effort needed to be instructional leaders modeling learning for teachers.

This study examines what one system in the United States did to support principal professional learning so that its leaders were equipped to transform the learning environments in which they lead teachers. Through monthly Principal Learning Communities (PLCs) in which they participated in half-day meetings every month, we observed over a three-year period the processes, content, and skill development coaching used by the system administrators, led by the superintendent primarily and other key central office leaders, to foster a program of support for principals as they worked to transform their schools.

\section{Introduction}

Accountability necessitates that principals walk a tightrope supporting a performance environment and culture that both drives and inspires teachers to higher performance in the classroom. Although there are inherent tensions in the role of the leader as supervisor, evaluator, and professional developer of teachers, high-stakes testing, sweeping curricular initiatives, and the proliferation of standards of practice have necessitated that principals understand and apply more complex skills in many different ways to support the instructional program and teachers.

\section{Changing Role of the Principal}

A school system that has a unified vision and mission for learning and is able to operationalize it in practice does so by building the learning capacity of leaders-who 
now must become the lead learners in their buildings. Principals can only transform their schools by supporting a culture that embraces the work teachers must do to lead students to learn in fundamentally different ways and settings. Essentially, "it is the principal, more than anyone else, who is in a position to ensure that excellent teaching and learning are part of every classroom" (Wallace Foundation, 2012, p. 3).

Without the capacity of the principal to evolve as the lead learner, the work of the school community will remain mostly static in developing a performance culture. Effective teaching thrives when principals create a culture of practice where they can ultimately:

- Establish a strong foundation through trust to grow partnerships with teachers, parents, students, site and system principals, and the central office;

- Allow students and teachers to take risks by putting safety nets in place;

- Focus on monitoring for results and establishing a readiness to be able to make mid-course changes;

- Create readiness for classroom transformations for new instructional practices and assessments; and,

- Align all efforts with the strategic plan to build system coherence.

For principals, this means that they must change from managing administrative tasks to becoming the "primary teacher developer and architect of collaborative learning" (Drago-Severson, 2012, p. 4).

\section{Principal Professional Development}

From the research and literature, professional development is effective when it extends over time (Darling-Hammond \& McLaughlin, 2011), includes follow-up as part of the process (Darling-Hammond \& Falk, 2013), is embedded within the work day at the site (Zepeda, 2015), promotes collaboration and reflection on practice (Creemer, Kyriakides, \& Antoniou, 2013), uses varied strategies (Drago-Severson, 2009), and is coherent, linking to other support processes such as supervision and coaching (Desimone, 2011; Zepeda, 2015). The research and literature about principal professional development not only mirror these ideas (Zepeda, Parylo, \& Bengtson, 2013) but also emphasize:

- Common learning experiences (Zepeda, 2013) in a professional learning community (Honig \& Rainey, 2014); 
- The development of networks (Shakeshaft, Becker, Mann, Reardon, \& Robinson, 2013) to mobilize knowledge with peer support (Chitpin, 2014) that reflects the "everyday fragmented world of schools" (Shakeshaft et al., 2013, p. 5);

- The context specific nature of the school and the system (Zepeda et al., 2013);

- Purposeful structures to be reflective in a collaborative space (Chitpin, 2014) to promote the "social construction of professional practice" (Browne-Ferrigno \& Muth, 2004, p. 471); and,

- Promote an action orientation to address the need to continually change practice (Somprach, Popoonsak, \& Ngang, 2014).

\section{Research}

Data for the present study were collected in tandem within a larger research effort that examined the tensions involved with a superintendent supervising and evaluating principals in a performance-based culture in one school district in the United States (Zepeda et al., 2014).

Research objectives. We wanted to learn about the professional learning provided to support principals in their transition to being the lead learner in a performance culture. We also wanted to examine the format and processes used during the monthly principal learning community (PLC) meetings.

Research methods. The research methods included shadowing primarily the superintendent (Gilliat-Ray, 2011; McDonald, 2005), observing the principal learning communities monthly meetings (Merriam, 1998), debriefing conversations (Onwuegbuzie, Leech, \& Collins, 2008), and analyzing artifacts (Corbin \& Strauss, 2008).

Data sources and collection. The primary data for this study came from five main sources gathered over four years: observations during the planning for professional learning, observations during PLCs and summer leadership retreats, observation of central office leaders conducting system-wide walk-throughs, agendas and other materials from the PLCs, and field notes from debriefing sessions with the superintendent. Secondary data regarding student performance were also used to highlight growth in achievement.

Data analysis. For each principal PLC, the primary researcher created a packet that included field notes, the agenda, and the notes from the debriefing. If there were notes from a shadow experience associated with a PLC, they were included in the packet. Meeting agendas were analyzed to examine both the order of and how information 
was presented to the school leaders. The agendas typically contained a set of essential questions designed to guide the learning of the leaders, as well as a breakdown of how the information was presented. Through a coding system, we linked PLC: meeting content, processes used to work with the content, and the activities that the principals engaged in during PLCs.

\section{Overview and Context of the Research Site}

Located in Athens, Georgia (USA), the Clarke County School District (CCSD) serves just over 13,000 students in which $51 \%$ are African-American, $23 \%$ are Hispanic, $20 \%$ are White, and $2 \%$ are Asian. The demographic student composition has remained relatively consistent since the 2009-2010 academic year. Nearly $12 \%$ of the students have English as their second language, approximately $9 \%$ of the district's students are served through the English as a Second Language (ESOL) program, about $11 \%$ of students in the district are served through gifted education programs, and about $11 \%$ are special needs students. Athens-Clarke County, the seat of the CCSD, has the third highest poverty rate among United States counties with populations between 65,000 and 249,000 . Over $30 \%$ of children in poverty-around $82 \%$ of students are eligible for the federal meal program and starting in the 2015-2016, all students in the district will receive free lunch through a federal Community Eligibility Provision (CEP) grant. In Athens, $49 \%$ of children live in single-parent homes and $19 \%$ of adults ( $>25$ years) did not complete high school-both significant risk factors that can keep students from graduating from high school. Despite these factors, the district's current graduation rate is $71.5 \%$, which is above the state average.

There are 2,691 employees-1,038 of which are teachers-with over 70\% having advanced degrees, 250 certified in gifted education, 16 National Board Certified teachers, and 7 Georgia Master Teachers. On average, teachers in the CCSD schools have 11.29 years of experience while nationally the average for all school systems is 13.8 years of experience (Goldring, Gray, \& Bitterman, 2013).

Leadership stability. The Clarke County School District, under the leadership of the current superintendent, has been remarkably stable in terms of principal longevity. The district has 21 schools, and a total of 14 principals have served as a principal in the district for the past six years. Eleven schools have had the same principal for the past six years. One school has experienced a principal change in the past six years, and three have had two principal changes. It is important to note that three of the principal changes were the result of current principals taking a position at another school within the district. Only one of the district's 21 schools has experienced a principal change 
in the past three years. The CCSD was home to the 2015 American Association of School Administrators (AASA) National Superintendent of the Year, the 2015 Georgia Superintendent of the Year, the 2015 Middle Level National Distinguished Principal, and the 2013 State of Georgia Secondary Principal of the Year.

State of accountability and CCSD. Since 2009, the CCSD has undergone numerous transformations, focusing teaching, leading, and learning on student growth and development, and each one of these transformations necessitated professional learning to support school principals and assistant principals. The work of developing school leaders was purposeful and tailored to the needs of the system, its students, teachers, and school-level leaders who had to become the lead learners to be able to work with teachers in ways that supported students. The performance culture in the CCSD was summarized by the superintendent as such, "We are going to get it right for every student when they walk through the doors of our classrooms." This new expectation required all teachers to use effective instructional practices and for principals to understand and support the uses of effective instructional practices by engaging teachers in conversations about their instructional impact on students.

The context of professional development in CCSD. Prior to 2009, professional learning for principals was a "sit and get" practice where external speakers would appear, present about some "generic" leadership concept, and then leave. Artifacts illustrated that many meetings dealt with managerial issues such as discipline, the examination of bell schedules for the middle and high schools, and so forth. Time for the principals to bring complaints to the superintendent was allocated; moreover, the meetings were described by a central office leader as a time for "leaders to complain" about students, teachers, and the community. The only constant across the meetings was the dedicated time, about an hour, for leaders to bring complaints to the superintendent. When examining artifacts, we could not discern any patterns of continuity of content, processes other than announcements, or activities in which principals were engaged in "doing" something other than listening or sitting. In other words, the principals were "not really converting the conversation into insightful action" (Fullan, 2008, p. 3, emphasis in the original). 


\section{Findings}

The findings offer insights on principal professional development that supports practices that have, in our opinion, the ability to drill deeply into a school's beliefs and operations about the work required to help leaders transform a culture where teaching results in students learning at a high level. It is not the intention of the authors to generalize the findings of this study to other school systems; rather, we wish to disseminate the practices of one school system in which PLCs for principals proved to be highly effective and meaningful for leaders as they focused on leading their schools to meet the needs of children. With this caveat acknowledged, we move to the three interrelated themes distilled from the data:

\section{- Beliefs Matter Only if Growth Matters}

- Transformational Professional Development Builds a Performance Culture

- Effective Professional Development Provides Safe Landing Change

\section{Beliefs Matter Only if Growth Matters}

Cultures are built on beliefs that direct systems through clarity of the work required to transform schools toward growth. In the CCSD, replacing the monthly meetings by building monthly professional learning communities (PLCs) for principals signaled the belief, urgency, and expectation for leaders to be lead learners. Foundational to this shift is that principals had to have not only the skills but also more importantly, the dispositions and the courage to lead transformations that mirrored the direction of the district in their own buildings. The foundational belief was growth matters and that beliefs only matter if there is action toward growth.

The transition to a PLC necessitated building a foundation to be able to create a performance culture centered on growth and common expectations. As a group the principals were in many ways grappling with that as a collective, they had to build among themselves a common culture of expectations that mirrored the superintendent's vision of what the CCSD had to become-accountable for students, "first" and teachers "a close second, but all of this only matters with a strong leader."

The urgency was visible: students overall were not necessarily faring well academically; the state had moved to standards-based curriculum and performancebased instructional strategies; and the state had data and processes for schools to assess and to measure school improvement efforts. Through the PLCs, CCSD created a dedicated space and forum where accountability and leadership could converge to build 
a performance-based culture. The journey included engaging principals in identifying the fundamental concepts of a PLC, including the norms and values for learning.

The first six months of the PLCs included small- and large-group discussions in which principals envisioned what a learning community of teachers would look like in their buildings and how collaborative cultures were needed for teachers to engage in talking about teaching and learning, using data to inform instructional practices, and how to tie data from the school improvement plan to actionable decisions made in classrooms. At the center of each one of these activities was an essential question positioning the principal as an instructional leader (e.g., How can instructional leaders use classroom observations to determine the performance level of a teacher in each CCSD Evaluation Standard?).

It took time to build trust and to operationalize expectations and this led the leaders to develop the Non-Negotiable Practices for High Student Performance. The nonnegotiable practices spelled out the expectations for a performance-based classroom. The second phase was to build a set of observable practices where the principals deliberated as a community what instruction would look and sound like in a classroom, examining the relationship between the non-negotiables and classroom observations. The third phase was to get principals in groups conducting system-wide classroom walk-throughs and then debriefing about what they observed. Building off this work, the next logical step was to develop a teacher evaluation system that would bring focus to the work leaders had to do to address teacher effectiveness while reinforcing the expectations the CCSD held. All of these efforts led the system and its teachers and leaders to move into the Commitments for High Student Performance.

Beliefs change over time. As example, the principals wrestled with their beliefs about teacher evaluation for an extended time, almost a year, as the CCSD Teacher and Leader Evaluation Systems were being built with input from leaders with the NonNegotiables and the Observable Practices. The beliefs surrounding teacher evaluation were articulated:

For leader and teacher evaluations to be meaningful, these systems must be:

- Developmental and differentiated to meet the needs of the professionals in the system;

- Congruent with building and district-wide school improvement plans and processes;

- Foundational to the ideals embraced in the agreed-upon work of the system; and, 
- Supported by the research and best practices related to the processes, procedures, and products of an evaluation system.

In a position statement made by the superintendent, "CCSD is fully committed to the ongoing learning and development of all our teachers and leaders across their careers" and moreover,

Our collective work has led to the development of a growth model to build instructional leadership capacity in the system, to develop a system that aligns with the instructional expectations found in a standards-based learning environment, and to develop ways to support teachers and teacher leaders at all levels-from exceptional to needing significant improvement.

In Table 1.1, the "old" and the "new" beliefs pre- and post-accountability culled from the findings of the present study served to ground the work of principals to be able to enact their roles as the lead learners and to develop the type of culture needed to transform teaching and learning in their buildings.

\section{Table 1.1}

\section{Old and New Beliefs Related to Accountability and the Work of the Principal}

\begin{tabular}{|l|l|}
$\begin{array}{l}\text { OLD BELIEFS-LIMITED ACCOUNTABILITY } \\
\text { ON SCHOOL AND TEACHER PERFORMANCE }\end{array}$ & $\begin{array}{l}\text { NEW BELIEFS-FULL ACCOUNTABILITY ON } \\
\text { SCHOOL AND TEACHER PERFORMANCE }\end{array}$ \\
\hline $\begin{array}{l}\text { I insulate teachers from parents } \\
\text { to minimize disruptions in the } \\
\text { learning process. }\end{array}$ & $\begin{array}{l}\text { I consistently engage parents and } \\
\text { teachers collectively to improve the } \\
\text { learning process. }\end{array}$ \\
\hline $\begin{array}{l}\text { I am in the halls for much of the day } \\
\text { to ensure an orderly environment } \\
\text { (for all students). }\end{array}$ & $\begin{array}{l}\text { I consistently am in classrooms most days } \\
\text { to ensure (a challenging) and engaging } \\
\text { environment for (all) students. }\end{array}$ \\
\hline $\begin{array}{l}\text { I create and follow a schedule to } \\
\text { complete teacher and staff evaluations } \\
\text { on time. }\end{array}$ & $\begin{array}{l}\text { I consistently create a schedule to } \\
\text { observe and to engage in conversations } \\
\text { related to teacher influence on learning. }\end{array}$ \\
\hline $\begin{array}{l}\text { I delegate curricular decisions to } \\
\text { instructional experts in the building. }\end{array}$ & $\begin{array}{l}\text { I consistently lead processes to make } \\
\text { curricular decisions that include } \\
\text { instructional experts. }\end{array}$ \\
\hline I monitor teacher planning. & I consistently engage in teacher planning. \\
\hline $\begin{array}{l}\text { I approve and arrange for professional } \\
\text { development. }\end{array}$ & $\begin{array}{l}\text { I consistently participate in professional } \\
\text { development with teachers and staff. }\end{array}$ \\
\hline
\end{tabular}




\begin{tabular}{|l|l|}
\hline $\begin{array}{l}\text { OLD BELIEFS-LIMITED ACCOUNTABILITY } \\
\text { ON SCHOOL AND TEACHER PERFORMANCE }\end{array}$ & $\begin{array}{l}\text { NEW BELIEFS - FULL ACCOUNTABILITY ON } \\
\text { SCHOOL AND TEACHER PERFORMANCE }\end{array}$ \\
\hline I enact teacher evaluation. & $\begin{array}{l}\text { I consistently hold the disposition that } \\
\text { an evaluation system is a way to engage } \\
\text { teachers in processes that promote } \\
\text { growth. }\end{array}$ \\
\hline $\begin{array}{l}\text { I leave classroom observation notes in } \\
\text { teachers' mailboxes. }\end{array}$ & $\begin{array}{l}\text { I consistently provide timely feedback to } \\
\text { teachers after all classroom observations } \\
\text { to have conversations about student } \\
\text { learning, engagement, the uses of digital } \\
\text { tools, and personalization that supports } \\
\text { teaching and learning. }\end{array}$ \\
\hline $\begin{array}{l}\text { I make announcements and disseminate } \\
\text { information to teachers. }\end{array}$ & $\begin{array}{l}\text { I consistently make teaching and learning } \\
\text { priority areas to engage teachers- } \\
\text { individually and school-wide in team } \\
\text { and faculty meetings, and so forth-in } \\
\text { conversations that focus on instruction. }\end{array}$ \\
\hline
\end{tabular}

During their work throughout the PLC, participants focused on developing the skills needed to change to the new work through engaging in inquiry, generative problem solving, dialogue, and reflection on their practices as school leaders. The discussions throughout the PLCs engaged principals to go beyond the nuts and bolts associated with "administrivia" and to focus more on the "talk about teaching" which provided the "inspiration" that linked together a new community. Although principals struggled at first, data revealed that their shift in roles and their efforts to foster trust were critical in creating the conditions necessary to build a learning community among themselves; however, the "struggle," the "strain," and the "awkwardness" supporting learning was necessary to transfer what they were doing in the PLCs within their own buildings.

\section{Transformational Professional Development Builds a Performance Culture}

In a performance culture, the end was clear-to improve student performance and to close the achievement gap. The work of the building and district leaders focused on how their collective work would change practices leading to that end. Transformative professional learning that builds a performance culture must be sustainable, where personal and professional commitments for ongoing learning permeate all that leaders do as they work with their teachers. Professional development that is transformational 
allows "the principal to get from point $A$ and $B$ and beyond while anticipating future needs and ways to meet those needs," according to the superintendent. Transformative professional development provides principals with numerous opportunities to personally and professionally reflect on their current practices, inquire about and implement new practices, and simultaneously to monitor the results in a public forum.

Content and processes. The content and processes used in the facilitation of monthly PLCs shifted a great deal the first year. There was variability in the time needed for discussions, working in small groups, and sharing ideas generated in small groups with the collective. The time spent on activities also changed as small groups gave signals that they needed more time, or if a discussion needed to be extended during larger group sharing. Principals began to ask critical questions of one another, and the superintendent. They wanted more time to process ideas, and the principals subtly stayed on topic by sharing strategies that they thought would work. In other words, the principals were inserting themselves through their practices in the process of learning. Around the same time, the superintendent and other central office leaders began to focus more intently on key areas such as poverty and learning, and they asked tough questions, "Can all students learn?" or "Do you know it when you see it?" related to high-yield instructional practices.

Transformational professional development is learning. School leaders cannot transform their cultures without first reflecting on their beliefs and making decisions on their own learning needs. It is through sifting through the "clutter" of one's own ideas that perspectives emerge. Through testing out ideas, engaging in conversations that ask tough questions, or sharing a perspective that might go against the grain, leaders were able to solidify and test their learning as they evaluated their own skills.

The principals had to not only take responsibility for their own learning during the PLCs, but they also were expected to apply the knowledge or the content or the application of what was being examined in the PLCs in their own buildings. The instructional services division would create in-depth activities that could be replicated in the principals' own buildings to engage in the same conversations with their teachers. In this way, principals could "lead these conversations" as the way to focus on "building capacity and fostering understanding."

Modeling techniques and approaches by the superintendent and the central office team, simulations geared to what conversations could possibly look like, and the "freeflow" of ideas helped to create synergy within the group. In many ways, the organization of content, the methods used in the delivery of content, and the applications to 
practice all led to demonstrate and connect high-performance expectations with highperformance learning models.

Conversations are at the heart of transformation. Conversations during the PLCs served to bring the principals along "when the topics were tough." For example, the principals engaged in simulations around the content and this essential question: How do leaders prepare to have difficult conversations with teachers about instructional practices that are necessary for students to achieve at high levels? Through conversation, principals acquired the skills and the confidence to engage teachers in the ongoing and formative work related to improving practices, and the same was true of the superintendent who often engaged principals in tough conversations when issues arose.

Conversations are more than feedback about performance. During the PLCs, the superintendent modeled numerous types of conversations that principals could have with teachers and other personnel at the site. Focus was placed on helping principals learn how to ask questions so that they were poised in a way that supported conversations leading to inquiry on practice.

Through the conversations, beliefs unfold. Beliefs drive practice. A portion of each PLC included a segment on promoting reflection. For example, three questions can support the development of reflection needed to examine beliefs that must lead to action-1. Do you believe education is important? 2. Do you believe you can lead learning at a higher level? 3. Do you believe that all kids are learning at their highest level? Each conversation segment of the PLCs was designed to keep the principal focused on student performance and data that tells whether or not students are learning. Through conversations, the superintendent modeled thinking and approaches to address the thorny issues principals encounter as they lead instruction.

Changing beliefs leads to action and results. Student achievement data from the years prior to the implementation of the performance culture, when compared to data gathered after the performance culture was established, suggests that meaningful changes have occurred. Tables 1.2-1.4 highlight the gains in student achievement on the standardized state-required tests for the two years prior to the performance culture being established to the two most recent years in which data were available. 
Table 1.2

Two-Year Average Comparison of Student Achievement for Grades 3-8

on Standardized State-Required Tests in Mathematics

\begin{tabular}{|c|c|c|c|}
\hline Grade & $2008 / 2009$ & $2013 / 2014$ & Gain/Loss \\
\hline 3 & $62.0 \%$ & $74.5 \%$ & +12.5 \\
\hline 4 & $54.5 \%$ & $70.5 \%$ & +16.0 \\
\hline 5 & $60.5 \%$ & $91.5 \%$ & +31.0 \\
\hline 6 & $57.5 \%$ & $73.5 \%$ & +16.0 \\
\hline 7 & $66.5 \%$ & $81.5 \%$ & +15.0 \\
\hline 8 & $56.5 \%$ & $85.5 \%$ & +29.0 \\
\hline
\end{tabular}

Table 1.3

Two-Year Average Comparison of Student Achievement for Grades 3-8 on Standardized State-Required Tests in English/Language Arts

\begin{tabular}{|c|c|c|c|}
\hline Grade & $2008 / 2009$ & $2013 / 2014$ & Gain/Loss \\
\hline 3 & $79.5 \%$ & $81.0 \%$ & +1.5 \\
\hline 4 & $78.0 \%$ & $82.5 \%$ & +4.5 \\
\hline 5 & $83.0 \%$ & $91.5 \%$ & +8.5 \\
\hline 6 & $79.5 \%$ & $84.0 \%$ & +4.5 \\
\hline 7 & $78.0 \%$ & $88.5 \%$ & +10.5 \\
\hline 8 & $83.0 \%$ & $92.0 \%$ & +9.0 \\
\hline
\end{tabular}


Table 1.4

Two-Year Average Comparison of Student Achievement for Grades 3-8 on Standardized State-Required Tests in Reading

\begin{tabular}{|c|c|c|c|}
\hline Grade & $2008 / 2009$ & $2013 / 2014$ & Gain/Loss \\
\hline 3 & $79.0 \%$ & $91.5 \%$ & +12.5 \\
\hline 4 & $79.0 \%$ & $87.0 \%$ & +8.0 \\
\hline 5 & $78.0 \%$ & $95.5 \%$ & +17.5 \\
\hline 6 & $83.0 \%$ & $93.5 \%$ & +10.5 \\
\hline 7 & $75.5 \%$ & $89.0 \%$ & +13.5 \\
\hline 8 & $84.0 \%$ & $96.5 \%$ & +12.5 \\
\hline *Establishment of Performance Culture Began in 2010 \\
*Student Achievement defined as Meeting/Exceeding Standards
\end{tabular}

Each grade level/subject combination experienced gains in student achievement since the implementation of the performance culture. The largest gains were achieved in mathematics, with a student achievement improvement in terms of percentage of students meeting or exceeding state standards, ranging from an increase of 12.5 to 31 percentage points. The range of increased student achievement was 1.5 to 10.5 percentage points and 8.0 to 17.5 percentage points for English/Language Art and Reading, respectively. The performance culture was implemented with one end, increasing student achievement. These results suggest changes implemented during this process had a meaningful impact.

\section{Effective Professional Development Provides Safe Landing Change}

The principals were being asked to approach leading in very different ways with the new work-focusing on data and implementing a new school improvement process, supporting teachers and a performance-based culture, engaging in different types of supervisory practices (e.g., frequent classroom observations), participating with teachers in professional learning, and using a new teacher evaluation system to promote teacher growth and development. It was a new day in CCSD.

Circles of support. During the monthly PLCs, principals were offered system and peer support as they worked to fine-tune their leadership skills-the very skills that had not necessarily been an expectation (e.g., being visible in classrooms). Also, with 
the move to a performance-based culture, principals had to learn how to generate new conversations about high-yield instructional strategies with their teachers. These conversations were important because other transformations that focused on school improvement were occurring simultaneously, and the principals needed to be leaders with the uses of data to inform instruction, the implementation of common planning time, and so forth. The expectation held by the system was that the principal had to be at the forefront of these transformations leading their schools in the "new work." At a key point during a PLC, the superintendent asked poignantly, "What do you [the principal] bring to the table when you meet and lead your teachers in our work?"

The PLC structure became the "safe learning ground" for principal learning. Through large- and small-group learning activities, book studies, and simulations, for example, the principals were able to share with one another as they learned from one another. Very often, principals were expected to carry out the very work accomplished in the PLCs in their buildings. By experiencing the "end result" of the work during the PLCs, the principals were better prepared to understand and lead the work in the buildings, and they were prepared to anticipate any "rough" terrain that might surface.

Safe landing change. In many ways, the principals were being asked to be change agents in their buildings to build a performance-based culture and to do so, the principals had to become the lead learners. They had to understand, recognize, and be able to discuss high-yield instructional strategies and so much more all in the context of transforming their schools. The work had to change, dramatically, and the principals were expected to be at the forefront to enact multiple and complex processes and procedures. The leaders had to add instructional leadership skills to their management and administrative skills. Student learning and engagement as well as the overall instructional program were at the forefront of the superintendent and the direction the CCSD was moving into to provide "every opportunity for students to achieve more."

Through the circles of support offered during the monthly PLCs, principals could enact safe landing change that became more engaging and meaningful as they exerted leadership outside of the PLCs. During the PLCs, the principals were able to seek out new knowledge, reframe knowledge, modify or adapt how knowledge gets translated into practice in other buildings, and then walk into their buildings more prepared to enact change.

Networks. Through the PLCs, principals were able to know that they did not have to "go about things alone" because they were able to develop a network. Repeatedly, the principals would make reference that a fellow principal was "one phone call away." 
When things did not go as expected, the principals had a built-in safety net-each other. The CCSD is broken up into clusters comprising two or three elementary schools, one middle school, and one high school. As a natural outgrowth of the monthly PLCs, principals would meet with the other principals in their cluster. These meetings would occur informally before the school day started or after school. Together, the principals would wrap their collective thinking around results, intentions, and efforts needed to modify a particular approach, a common problem of practice, or share resources with one another.

\section{Discussion and Summary}

In the United States, federal and state policies, statutes, and systems are rooted in accountability. Situated within the context of school districts are internally held performance expectations that govern the ways schools run. Building a culture of performance expectations is much different than enforcing compliance with policies and regulations associated with an internal or external push for performance. The school district was dedicated to investing in the professional development to transform building level leaders. Whereas, the superintendent was resolute in his belief that to enact the type of changes that were needed to transform schools, principals were central to the process by honing skills that allowed them to lead complex and multi-dimensional systems.

Changing a culture centered on performance occurs over time and to be the lead learner, the principal must be in a position to support core changes at the building level. The movement to a PLC was a time-intensive process that involved the principals in changing their frames of reference from attending monthly meetings to being an active learner developing the skills needed to support cultural shifts aligned to the transformations expected in the district.

An interesting finding of this study was that learning was leading and in many ways that the new leader is really the new learner. When leaders as a whole are learners, they are ready to make changes in their practices. Understanding this finding lends support for the need for principal professional learning that supports the construction of knowledge.

To grow and develop as the lead learners of their buildings, principals must engage in professional learning opportunities that magnify focus on the leadership strategies 
that can propel and sustain transformational learning environments within their own buildings. Transformative professional learning to build a performance culture can only be sustained when commitments for ongoing learning permeate all that leaders do as they work with their teachers. Transformative professional development requires principals to engage continuously in personal reflection, to inquire on their practices, and to monitor the results of their efforts individually and publicly.

The results of this study amplify numerous findings from other studies, namely that professional learning for principals yields positive results when they engage in common and "like" learning experiences (Honig \& Rainey, 2014) in a collaborative space (Chitpin, 2014) that supports an action orientation to solve the thorny issues of practice (Somprach et al., 2014). Our study illustrates that it was strategic professional development that created a clear roadmap to support a performance culture. For this school system, a performance culture appears to be sustainable through the commonly held beliefs and shared learning as compared to a set of individual and independently driven practices. Moreover, coherence between the system, the schools, and the school leaders' actions and beliefs was enhanced throughout the ongoing PLC meetings.

While the scope of this article is about principal professional development and the processes and lessons learned from the experiences in a PLC, one interesting aspect of the study signals the importance of the superintendent in framing what is needed to change the culture of the school system and the ability to drill down to the building level, to accept the responsibility to support principals, and to hold firm on expectations for principals to be the lead learners. The principals in this PLC were accomplished in every way possible; however, the principals had to reconcile the differences between their own beliefs and abilities against what was needed to support a culture for success for all students. In the final analysis, principals need support to make sense of their work, to learn from one another, and to stretch their skill set. 


\section{References}

Browne-Ferrigno, T., \& Muth, R. (2004). Leadership mentoring in clinical practice: Role socialization, professional development, and capacity building. Educational Administration Quarterly, 40 (4), 468-494. doi:10.1177/0013161X04267113

Chitpin, S. (2014). Principals and the professional learning community: Learning to mobilize knowledge. International Journal of Educational Management, 28(2), 215-229. Retrieved from http://dx.doi.org/10.1108/ IJEM-04-2013-0044

Corbin, J., \& Strauss, A. (2008). Basics of qualitative research (3rd ed.). Thousand Oaks, CA: Sage.

Creemers, B., Kyriakides, L., \& Antoniou, P. (2013). Teacher professional development for improving quality of teaching. New York: Springer.

Darling-Hammond, L. (2012). Creating a comprehensive system for evaluating and supporting effective teaching. Stanford, CA. Stanford Center for Opportunity Policy in Education. Retrieved from https://edpolicy.stanford. edu/

Darling-Hammond, L., \& Falk, B. (2013). Teacher learning: How student-performance assessments can support teacher learning. Washington, DC: Center for American Progress.

Darling-Hammond, L., \& McLaughlin, M. W. (2011). Policies that support professional development in an era of reform. Phi Delta Kappan, 92(6), 81-92. Retrieved from www. pdkintl.org/publications/kappan/

Davis, T. (2013). McRel's research-based teacher evaluation system: The CUES framework. Denver, CO: The Center for Educator Effectiveness, McREL International. Retrieved from http://www.mcrel.org/

Desimone, L. M. (2011). A primer on effective professional development. Phi Delta Kappan, 92(6), 68-71. doi:10.2307/25822820

Drago-Severson, E. (2009). Leading adult learning: Supporting adult development in our schools. Thousand Oaks, CA: Corwin Press.
Fullan, M. (2008). Leading change. In Conversation, 1(1), 2-8. Ontario Ministry of Education. Retrieved from http://www.edu. gov.on.ca/eng/policyfunding/leadership/ InConversation.html

Gilliat-Ray, S. (2011). 'Being there': The experience of shadowing a British Muslim hospital chaplain. Qualitative Research 11(5), 469-486. doi:10.1177/1468794111413223

Goldring, R., Gray, L., \& Bitterman, A. (2013). Characteristics of public and private elementary and secondary school teachers in the United States: Results from the 2011-12 Schools and Staffing Survey (NCES 2013-314). U.S. Department of Education. Washington, DC: National Center for Education Statistics. Retrieved from http://nces.ed.gov/ pubsearch

Heck, R. H., \& Hallinger, P. (2009). Assessing the contribution of distributed leadership to school improvement and growth in math achievement. American Educational Research Journal, 46(3), 659-689. doi:10.3102 /0002831209340042

Honig, M.I., \& Rainey, L.R. (2014). Central office leadership in principal professional learning communities: The practice beneath the policy. Teachers College Record, 116(4), 1-48. Retrieved from http://www.tcrecord.org/ Articles.asp/

McDonald, S. (2005). Studying actions in context: A qualitative shadowing method for organizational research. Qualitative Research, 5(4), 455-473. doi:10.1177/1468794105056923

Merriam, S. B. (1998). Qualitative research and case study applications in education. San Francisco: Jossey-Bass.

No Child Left Behind Act of 2001. (NCLB). Pub. L. No. 107-110, § 115, Stat. 1425. 2002.

Onwuegbuzie, A. J., N. L. Leech, \& A. M. T. Collins. (2008). Interviewing the interpretive researcher: A method for addressing the crises of representation, legitimization, and praxis. International Journal of Qualitative Methods 7(4): 2-17. Retrieved from https:// ejournals.library.ualberta.ca/index.php/ IJQM/ 
Shakeshaft, C., Becker, J., Mann, D., Reardon, M., \& Robinson, K. (2013). Toward fidelity: Simulation-based learning for school principal preparation and professional development. Planning \& Changing, 44(1/2), 5-20. Retrieved from http://education.illinoisstate. edu/planning/

Somprach, K., Popoonsak, P., \& Ngang, T.W. (2014). Collaborative action professional development of school principals. Procedia-School and Behavioral Sciences, 116, 77-81. doi:10.1016/j.sbspro.2014.01.171

Wallace Foundation. (2009). Assessing the effectiveness of school Leaders: New directions and new processes. A Wallace Foundation Perspective, 7-8. New York: Wallace Foundation. Author. Retrieved from http://www.wallacefoundation.org/ knowledge-center/school-leadership/ principal-evaluation/Documents/Assessingthe-Effectiveness-of-School-Leaders.pdf

Wallace Foundation. (2012). The making of a principal: Five lessons in leadership training. New York: Author. Retrieved from www.wallacefoundation.org/
Zepeda, S. J. (2013). The principal as instructional leader: A practical handbook (3rd ed.). New York: Routledge.

Zepeda, S.J. (2015). Job-embedded professional development: Support, collaboration, and learning in schools. New York: Routledge.

Zepeda, S. J., Lanoue, P. D., Price, N. F., \& Jimenez, A. M. (2014). Principal evaluation-linking individual and building-level progress: Making the connections and embracing the tensions. School Leadership \& Management, 34(4), 324-351. doi:10.1080/13632434.2014.9 28681

Zepeda, S.J., Parylo, O., \& Bengtson, E. (2013). Analyzing principal professional development practices through the lens of adult learning theory. Professional Development in Education, 39(4), 1-21. doi:10.1080/19415257. 2013.821667 


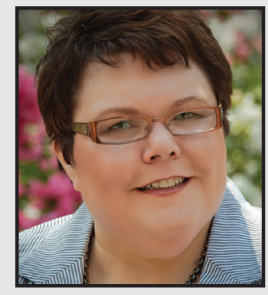

Sally J. Zepeda, PhD is a Professor in the Department of Lifelong Education, Administration, and Policy in the College of Education at the University of Georgia. Her research, teaching, and service spans teacher and leader supervision and evaluation, professional learning, and principal and superintendent development. Dr. Zepeda serves as the system-wide professorin-residence with the Clarke County School District through its partnership with the University of Georgia. Her latest book is JobEmbedded Professional Development: Support, Collaboration, and Learning in Schools (Routledge, 2015). She is the inaugural Master Professor (University Council of Educational Administration) and has worked with school systems nationally and internationally.

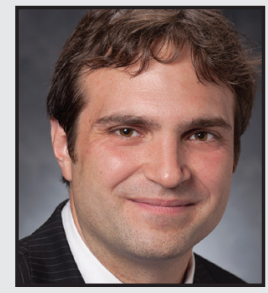

Albert M. Jimenez, PhD is an Assistant Professor and the Director of the Master's Program at Kennesaw State University in Educational Leadership. Dr. Jimenez's research, teaching, and services are primarily in the areas of teacher and leader evaluation, assessment, evaluation, professional development, and strategies impacting English Learners.

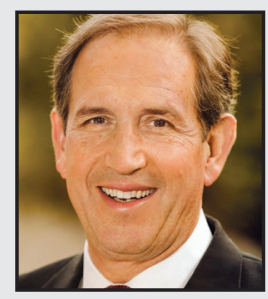

Philip D. Lanoue, PhD is the Superintendent of the Clarke County School District, the 2015 AASA (American Association of School Administrators) National Superintendent of the Year, and the 2015 Georgia Superintendent of the Year. Dr. Lanoue has been named one of the nation's top 50 education innovators in digital learning by the Center for Digital Learning and Converge magazine. He is a national speaker on topics including personalized learning, classroom environments, and leadership. He is also an Adjunct Assistant Professor at the University of Georgia in the Department of Lifelong Education, Administration, and Policy. 